\title{
THE IMPACT OF CONDITIONALITY ON THE TEMPORAL ASPECT OF ACCESSION PROCESS OF CANDIDATE STATES TO THE EU: TURKEY AND SERBIA IN COMPARATIVE PERSPECTIVE
}

\author{
Pınar ERKEM
}

\begin{abstract}
The aim of this paper is to examine whether the EU implements the accession criteria objectively to all candidate states. The temporal dimension of the accession process and the impact of conditionality are the focus points to analyze. For this purpose, a comparison of Turkey and Serbia with regards to their EU accession processes is conducted. The cases are composed of the longest waiting candidate and the last candidate with relatively fast moving process. The cases are compared according to the time they spent in the way to membership, the conditions that have put forward by the EU and the prizes they received in the process, i.e. the free movement right. The findings point out to the difference in the implementation of conditionality for the two candidate states both in terms of quality and quantity.
\end{abstract}

Keywords: conditionality, enlargement, EU, Turkey, Serbia

\section{ADAY ÜLKELERİN AB'YE KATILIM SÜRECİNDE KOŞULLULUĞUN ZAMANSAL AÇIDAN ETKİSİ: KARŞILAŞTIRMALI PERSPEKTIFLETÜRKİ- YE VE SIRBİSTAN ÖRNEKLERİ}

\begin{abstract}
ÖZ
Bu çalışmanın amacı Avrupa Birliği’nin (AB) katılım kriterlerini tüm aday ülkelere objektif biçimde uygulayıp uygulamadığını incelemektir. Analizin temel odaklarını katılım sürecinin zamansal boyutu ve koşulluluk politikasının etkisi oluşturmaktadır. Bu amaçla, Türkiye ve Sırbistan'ın AB'ye katılım süreçleri karşılaştırılacaktır. Bu iki örnekten biri en uzun süredir katılım için beklemekte olan ülke iken diğeri sürece en son katılan ve görece olarak hızlı ilerleyen bir ülkedir. Örnekler üyelik öncesi geçirdikleri süreçler açısından karşılaştırılmaktadır; zamansal boyut, AB tarafından sürülen koşullar ve süreç içerisinde elde edilen ödüller, örneğin dolaşım serbestisi, ele alınmaktadır. Ulaşılan sonuçlara göre koşulluluk ilkesinin uygulanmasında iki aday ülke için niteliksel ve niceliksel açılardan farklılıklar tespit edilmiş ve ortaya konulmuştur.
\end{abstract}

Anahtar sözcükler: Koşulluluk, genişleme, AB, Türkiye, Sırbistan

\footnotetext{
- An earlier draft of this paper was presented in International Studies Association Annual Convention in 2014 at Toronto, Canada. Dr., Istanbul University, Faculty of Economics, Department of International Relations and Political Science. pinarerkem@gmail.com
} 


\section{BUJSS}

9/1 (2016), 118-133

European integration has been a cooperation project from the beginning and carries an ambition to build peace in the region. While transforming from being an economic community to a political union, it created and adopted a particular body of values. These values have been standardized and called as the Copenhagen criteria. The European Union (EU) expects its current and future members to abide with these criteria. It implements them on the future members through its most effective foreign policy strategy, which is enlargement. The enlargement policy utilizes conditionality ${ }^{1}$ as a tool to implement the Copenhagen standard to the accession countries. As a result, the EU norms began to expand and be adopted in the region as a general standard.

Eastern borders of the EU enlargement contain the former Yugoslav states in the Balkans and Turkey. The priority of the EU is to establish peace and stability in its 'backyard', which has experienced violent conflicts in the recent history. The EU aims to support establishment of stable democracies in this region and therefore developed policy strategies to create cooperation and export the European norms. Within this framework, the EU developed its relations with Serbia and by accepting her candidacy, opened the doors of membership to the Union. On the other hand, Turkey, at the easternmost point of European border, is the oldest country on the waiting list for membership. Turkey has a long history with the European community/union, but she has only gained membership status in 1999 and still has a long way to go. Serbia, on the other hand, has a much faster pace in the way to full membership though it is a relatively new state with a violent conflict in her contemporary history.

This paper tries to examine whether the EU implement the accession criteria objectively to the candidate states. The domestic politics of these countries being left aside, the membership procedures of Serbia and Turkey will be compared, in order to evaluate the membership standards of the EU, to see whether they are standard for all. While Turkey has been the country which spent the longest period on the waiting line, Serbia gained a rather fast momentum. Therefore, comparing the slowest and the relatively fast membership processes may show the differences in a clearer way. First of all, the history of accession processes will be compared. While doing that, mainly three areas are chosen as the focus points of the comparison fields; existence of a significant condition for membership, condition of good relations with neighbors and condition and realization of the free movement right. In the case of Serbia there is a significant condition, while Turkey faces different conditions in time. Regarding relations with neighbors, both countries faced problems, Serbia with Kosovo and Turkey with first Greece and then Cyprus. Finally, free movement right is chosen as it is a rather significant determiner in showing the difference in the policies of the EU.

Comparing the EU relations with the two countries on these areas will give an idea on whether the pace of

${ }^{1}$ For a detailed study on conditionality and its impact on Turkey and the EU relations, see Akgül Açıkmeşe, 2010. 


\section{BUJSS}

9/1 (2016), 118-133

membership is similar or different for the two candidates. While examining these areas, the reasons for the pace difference will be overviewed to analyze the possible reasons behind the difference. As a result, the findings of the paper aim to contribute to the assessment of the enlargement criteria.

\section{The European Union Enlargement Strategy and the Balkans}

The EU enlargement policy is regulated in the EU agreement article 49, which directs to article 6. According to this, any European state which is respectful to the founding principles of the EU that are liberty, democracy, respect for human rights and fundamental freedoms and the rule of law, can apply to become a member (EU, 2009; 12-35). These are part of the criteria that are necessary to become a member and were determined in 1993 Copenhagen Summit so they are called as the Copenhagen Criteria. The applicant states are required to oblige with these political and economic criteria and to have the capacity to implement acquis communitaire (EU, 1993; 13). The political criterion consists of having a stable democracy, rule of law, respect for and protection of human rights and fundamental freedoms. Economic criterion requires a functioning economy and ability to cope with the competitive free market of the Union.

The EU Commission, which carries on the accession talks, follows three main strategies during the enlargement process. These are consolidation, communication and conditionality. Conditionality is the most effective strategy among all. Any state which desires to reach full member status, should follow the necessary reforms that are communicated by the Commission. The reforms are periodically monitored and the recommendations are reported. Membership is conditioned on the implementation of the required reforms. Thus, the EU becomes a powerful and influential external actor to provide structural transformation and practical implementation in the candidate states.

The EU has built a different enlargement strategy in relation with the Balkan states (excluding Croatia). While the membership perspective was clearer in the past enlargements and the required reforms were determined based on the whole acquis, for the Balkan states including Serbia, a new process, called Stabilization and Association Process (SAP) has implemented, in which membership was a potential but not certain. Required reforms are not based on the whole acquis but only on particular areas that the EU determines (Renner, Trauner, 2009; 453). This procedure was criticized as it did not provide full membership perspective but aimed to transform the political structures of these countries. However, the EU provided full membership perspective after the preconditions were satisfied. It utilized the SAP to build peace and cooperation in the region. For example in 2005 an energy community was established among Croatia, Bosnia-Herzegovina, Serbia, Montenegro, Macedonia, Albania, Romania, Bulgaria and Kosovo. By this kind of cooperation procedures, the EU tried to develop peace and cooperation, also had the chance 


\section{BUJSS}

9/1 (2016), 118-133

to see the desire and compatibility of these states for the EU membership (Renner, Trauner, 2009:

458-461; Energy Community, online 2012). Additionally, this process prepared these countries for the EU membership.

\section{Serbia's Relations with the EU and the Impact of Conditionality in the Accession Process}

With the breakup of the Socialist Federal Republic of Yugoslavia, Serbia and Montenegro established the Federal Republic of Yugoslavia in 1992. Even though the state was new, the governing elite remained the same, under the leadership of Slobodan Milosevic until 2000 (Lazic, Vuletic, 2009; 988). After Milosevic left power and was given in the International Criminal Tribunal for the former Yugoslavia (ICTY) due to the war crimes, the relations between Serbia and the EU has progressed positively (Commission, 2002; 3-5). In 2006, Montenegro preferred independence in a referendum and thus, Serbia became the legal successor of the state and named the state as the Republic of Serbia.

The EU has given importance to the consolidation of democracy in the Balkans and therefore started the SAP after the Council's decision in Santa Maria da Feira in 2000, thus giving the western Balkan states the prospect of the EU membership (European Parliament, 2014). In June 2003, this decision was repeated and Thessaloniki agenda was accepted for the integration of western Balkan states to Europe (General Affairs and External Relations, 2013). After these decisions, formal political dialog between the EU and Serbia started. In 2004, the Council started the European Partnership which would organize assistance to Serbia and Montenegro (European Council Decision, 2006). It also set the necessities for Serbia to come closer with the EU (European Commission, 2005; 54). The EU also provided financial support to Serbia in order to consolidate democracy after the removal of Milosevic from power. The EU was the most generous external actor to support infrastructural and administrative development of Serbia since 2003. With the membership prospect becoming clearer, these aids were utilized in the harmonization with the acquis (Presnall, 2009; 664-676). In accordance with this assistance, Serbia progressed in democratization and took measures like increasing participation of women in political parties and parliament or removing the threshold for minority parties (Orlovic, 2008; 206).

Serbia's political system was called a hybrid regime for the period of 1990 s to 2003 as it had authoritarian features despite of having elections. In the period of 2004-2006, it was a system of elections without consolidated democracy, which means there weren't enough measures to prevent it to become authoritarian (Pavlovic', Antonic', 2007; 82-83). In this period, Serbia's cooperation with ICTY was questioned and Serbia was complaining from the pressure coming from the EU. Moreover, 2006 constitution was perceived as a step backwards from democracy, as it was created through undemocratic procedures (Ramet, 2011; 274-275). 


\section{BUJSS}

9/1 (2016), 118-133

Thus, it will be said that Serbia's accommodation with democracy criterion of the EU was questionable in this period.

Serbia's EU prospect began in 2005 with the negotiations of Stabilization and Association Agreement (SAA), which set forth the requirements to fulfil to be eligible for membership application to the EU (Commission, 2005; 10). The SAA can be perceived as conditions for Balkan states, which prepare them for the membership process. The EU put the condition to cooperate in the arrest and extradition of the war criminals to the ICTY for Serbia in order to sign the SAA (Commission, 2007a; 4). Serbia made progress in the cooperation on this issue, thus removed the conditions on the signing of the SAA but the cooperation emphasis continued for the realization of full membership as full cooperation was required (Commission, 2007b; 6). With the signing of the SAA in 2008, the EU committed itself in the strengthening of democracy and rule of law in Serbia, political, economic and institutional stability of Serbia and its region, development of political dialogue, fulfilment of the economic criterion, international cooperation, regional cooperation and development of a free trade area between the parties (The European Community; 9-10).

Commission's 2005 enlargement strategy paper emphasizes that enlargement is the most powerful policy tool of the EU and this policy can help to turn the ex-communist regimes of central and eastern European states into modern and well-functioning democracies (The European Community; 9-10). That clearly shows that the EU perceives Eastern Europe or the Balkans as priority areas to influence and expand its norms. That can be the reason that despite of the shortcomings of Serbia's fulfilment of criteria, the relations had showed rapid progress in relatively short time period. According to the same paper, Serbia had weaknesses in political structures, particularly in constitution. Additionally, there was lack of dialogue between Kosovo and Belgrade, which caused problems on migrants. Lastly, full cooperation with ICTY was yet required, which had political costs in domestic politics as the public opinion was supporting the former generals due to nationalist sentiments (Schimmelfennig, 2008; 930). Despite of the criticisms or requirements of the EU, repeating the decision of Thessaloniki summit that all western Balkan states can be members (Schimmelfennig, 2008; 930), was a good motivation for these states to continue reform and progress. Therefore it can be concluded that, even if the demands of the EU are perceived as 'costs' for Serbian domestic politics, the benefits of the relationship with the EU still outweigh the costs. The reason for this is the EU supplied Serbia with an attainable prize; the full membership.

With regards to the relations with neighbors, the most significant issue was related with Kosovo's declaring independence from Serbia in 2008. As a remnant of dissolution of Yugoslavia and transformation of a multi-national federation into a majoritarian state by Serbia, Kosovo issue tried to be resolved through 


\section{BUJSS}

9/1 (2016), 118-133

the inclusion of international actors including the EU. However, Serbia did not recognize the recommendations of the international actors, rejecting a future independence of Kosovo (Weller, 2012; 219-230). As a result, Kosovo declared independence and that decision was recognized vastly by international community, except by the Russian Federation. Even though Serbia opposed this secession and opinion of the International Court of Justice was sought, the decision of the Court was not against the independence declaration (Weller, 2012; 219-230). As most of the EU member states recognized the independence of Kosovo, Serbia withdrew her ambassadors from those EU member states at the first stance but with the EU's interference, reappointed her envoys. Even though the EU gives importance for the candidate states to have good neighbor relations, the impact of Kosovo conflict to the EU and Serbia relations remained minimal. The EU found it positive that Serbia opposed the independence of Kosovo only in terms of diplomatic ways and did not resort to violence (Commission of the European Communities, 2008; 5).

Regarding the free movement, the EU acted positively towards Serbia even before making a membership application. In 2009 the EU lifted visa obligation for Serbian citizens so provided free movement in the Schengen area (Commission of the European Communities, 2009; 5). Serbia applied for membership to the EU just after receiving this right. Thus, Serbia did not have trouble in the free movement of people clause, and gained this right even before the beginning of accession talks.

The main obstacle on the full membership process had been the full cooperation with ICTY, through delivering war criminals Ratko Mladic and Goran Hadzic who were believed to be hidden in Serbia (Communication, 2009; 1). As both of them were delivered to the court, Serbia fulfilled the condition and therefore removed the barrier on full membership. So, the Commission approved the membership application of Serbia in the end of the same year, 2011, by declaring that Serbia has proceeded considerably in the fulfilment of the Copenhagen criteria and the reforms that the SAA foresaw (Communication, 2011; 1). Considering the determination and progress of Serbia in the way to the EU membership, Serbia was formally declared as a candidate state in March the 1st, 2012 and the accession talks commenced in 2014.

\section{Turkey's Relations with the EU and the Impact of Conditionality in the Accession Process}

After the collapse of the Ottoman Empire, winning a liberation war against the occupying states, Republic of Turkey was established in 1923. Formed as a secular, modern republic, Turkey went through a decade of reforms. In line with the Ottoman policy, Turkey identified her foreign policy and identity as being a part of the European state system (Schimmelfennig, 2008; 931). ${ }^{2}$ During the Second World War and afterwards during the Cold War period, Turkey placed herself with the Western bloc and participated in Western organizations like the United Nations, North Atlantic Treaty Organization, Organization for

\footnotetext{
${ }^{2}$ For a detailed study on conditionality and its impact on Turkey and the EU relations, see Akgül Açıkmeşe, 2010.
} 


\section{BUJSS}

9/1 (2016), 118-133

Economic Co-operation and Development, or Council of Europe (Eralp, 1998; 37-39).

In accordance with this identification, due to economic development desire, trade privileges and also because of the need to counter balance the disputed neighbor Greece, Turkey aimed for European Economic Community (EEC) membership (Müftüler-Bac, 1997; 54). As a result of Turkey’s application in 1959, an Association Agreement was signed in $1963^{3}$. At the same year, association agreements were concluded both with Turkey and Greece with the perspective of full membership (Müftüler-Bac, 1997; 54-56). From a contradicting perspective, these agreements did not provide full membership prospect, so the first membership application of Turkey was in 1987. According to the EU, 1959 application was for associate membership and 1987 application was for full membership (European Commission, Enlargement: EU Turkey relations, online).

With 1963 Association Agreement, a 22 year period was foreseen for the parties to harmonize their policies for economic integration which will end up in full membership to the Community (Müftüler-Bac, McLaren, 2003; 20). It was planned that, in the end of 22 years period, Turkey would be ready for full membership, enter into a Customs Union and harmonize with common taxation and agriculture policies. However, among all these, only Customs Union was realized. In 1970, an Additional Protocol was signed as the end of the preparation period and a date for entering the Customs Union was set.

Due to the economic and political crises in 1970s, the relations had deteriorated. Turkey had another military intervention in 1971. Meanwhile, Cyprus problem emerged as a factor to effect the relations with the 1974 intervention of Turkey which was a response to the failed military intervention of the junta in Greece to overthrow Cypriot government and annex Cyprus to Greece (Yakinthou, 2012; 235). In order to protect the Turkish minority from the ongoing violent conflict, Turkey used the rights of being a guarantor power for the status of Cyprus and realized a military intervention, which was followed by another intervention to increase the sphere of influence. This incident complicated Turkey's relations with Greece and Cyprus. Turkey refused to internationally recognize the Republic of Cyprus which was not containing the Turkish Cypriots. Even though there has been no major violent conflict following 1974, relations with Cyprus remains to be an obstacle to Turkey's membership prospect.

Moreover, the decision of the European Community (EC) to establish the Mediterranean policy without involving Turkey in the decision making bodies and also not including Turkey in the common agricultural policy caused a negative impact on Turkey (Müftüler-Bac, 1997; 56-57). This kind of exclusion negatively affected Turkey's perception and ambition to join the community. Additionally, the promised free movement right was not realized by the EC. As a result of all of these events, Turkey had frozen the relations in 1978

${ }^{3}$ For a detailed study on conditionality and its impact on Turkey and the EU relations, see Akgül Açımeşe, 2010. 


\section{BUJSS}

9/1 (2016), 118-133

by activating self-protection clause (Balkır, 1998; 56, Öniş, 2000; 468).

At the time of the reestablishment of the relations, Turkey had the third military intervention of her history in 1980. Following the shift to junta rule, in 1982 a new and undemocratic constitution was made. When increasing human rights abuses was coupled with these developments, the EC suspended the relations with Turkey. As another influential event, in 1981 Greece, with whom Turkey had problematic relations, was accepted as a member state, having a vote against Turkey inside the EC decision-making bodies for about two decades.

Re-establishment of relations between the EC and Turkey happened gradually in 1986-8. Turkey applied for full membership to the EC in 1987, which accepted new members a year ago. This application was responded two years later, in 1989. The response was rather unclear; it accepted the full membership prospect of Turkey but denied the application due to being in the deepening phase. Turkey was found un-absorbable in that moment, as the EC had just accepted new members, therefore it had to deepen, and also was in the process of commencing the Common Market. Additionally at that time, Turkey faced additional criteria; problems with Greece and Cyprus began to take part in the conditions. Democracy, human rights and pluralism were also included in the agenda as conditions while the EC started to change from an economic community to also a political one, particularly with 1993 Copenhagen Summit. Therefore it can be said that, Turkey's condition list experienced an increase as the community enlarged and deepened.

Turkey was given a candidate country status in 1999. With the National Program accepted in 2001, Turkey started to implement the acquis and necessary reforms. In 2002, a reform period started, in which reforms in the areas of freedom of speech and press, prevention of torture, freedom of political parties, abandoning of death sentence, and right of minority groups to use their mother tongue in press had realized (Müftüler-Bac , McLaren, 2005; 26, Eralp, 2004; 80-81, Hale, 2003; 110-122). As the reforms continued in 2003, the Commission advised that Turkey abided with the political criteria (Commission of the European Communities, 2004; 3).

However, in 2004, an internal paper about the issues arising from Turkey's membership perspective stated that this enlargement is different than the previous enlargements due to Turkey's size, population, geopolitical situation, economic, security and military potential, and cultural and religious identity (Commission of the European Communities, 2004; 4). On the one hand this evaluation can be regarded as being realistic but on the other it is open to criticism. The EU may have concerns on the possible influence on the decision-making of a highly populated country in the Parliament and the Council (Commission of the European Communities, 2004; 4). These are practical issues that can be evaluated. But there are other issues 


\section{BUJSS}

9/1 (2016), 118-133

which are not compatible with the other membership procedures. First of all, it is unclear that what is meant by the 'cultural identity' and in which aspects Turkey is different. Secondly, discussing something that is called 'religious character' within enlargement policy, comparing with other enlargements, takes us to the point that the EU may have religious prejudices against memberships. It also points to an unexpressed internal problem of the EU on self-identification. As Nathalie Tocci mentions, the EU's stance towards Turkey is a sensitive issue as it tends to be correlated with its stance towards Islam or Muslim countries and a possible rejection of Turkey's membership will be evaluated as "an affirmation of an exclusivist and essentialist European identity" (Tocci, 2012; 147).

After the Commission's advice in 2004, accession talks with Turkey began in 2006. Meanwhile the Republic of Cyprus also became a member of the EU. However, the Republic of Cyprus was accepted as a member state, without a resolution to the conflict in Cyprus between the Greek and Turkish Cypriots.

Therefore, Turkey faces the veto of the Republic of Cyprus on the progress of the talks. As Turkey does not recognize and does not have any diplomatic relations with the Republic of Cyprus, Turkey does not open ports and airports to vessels coming from the Republic of Cyprus. As a result, the Council decided that eight of the chapters are not going to open for discussion until Turkey opens its ports and airports. Additionally some chapters are frozen due to veto from Cyprus and France on particular issues. Moreover, none of the other chapters will be closed until the problem with Cyprus is solved (European Commission, Enlargement: EU - Turkey relations, online). Yet, only one chapter is completed and closed (science and research), fourteen chapters out of thirty-three chapters are open.

Free movement of workers is labelled as hard to adapt to acquis. In 2013, an agreement was concluded between the two sides regarding simplification of visa requirements for Turkish citizens, in return of Turkey's signing the readmission agreement of refugees and as of October 2014 they entered into force (European Commission, 2013; 3, European Commission, 2014; 1). Thus, it can be said that free movement right is not foreseen in a close future but is rather used as a bargaining tool. Considering the long history of Turkey and the EU relation and the relatively low pace of development in the relations, in turn, decrease the hope and willingness of the governments to carry on with the reforms.

Even if the accession talks finalize successfully, Turkey's membership will be put in a referendum in some of the member states like France and Austria (Schimmelfennig, 2008; 920). Therefore, full membership prospect for Turkey is unclear. As Frank Schimmelfennig asserts, "nothing short of a credible conditional accession perspective has proven effective" (Schimmelfennig, 2008; 919). In the case of Turkey, lacking improvement in policy areas like free movement or unclear status of membership due to 


\section{BUJSS}

9/1 (2016), 118-133

referendum decisions of some member states has affected the willingness of Turkey to take steps forward, as the possibility of actual membership lost credibility.

Moreover, acceptance of the Republic of Cyprus as a member state to the EU despite of the continuing conflict was perceived as an unjust policy. The referendum of the UN peace plan, the so called "Annan Plan" for the for re-unification of the two communities, which took place in Cyprus before the membership, was voted down by the Greek Cypriots while the Turkish Cypriots voted in favor. That caused a loss of trust to the EU in Turkish public opinion, as the acceptance of the Republic of Cyprus to EU without the Turkish Cypriots was perceived as a punishment of the Turkish Cypriots even though they accepted the solution plan. Therefore, putting forward the international recognition of the Republic of Cyprus as a condition to Turkey's membership is an unbearable cost for Turkey, in return of an unclear membership possibility, which has been on the rack for a very long time.

As a last but not the least point to mention, democracy rating for Turkey has been diminishing since 2013. According to the Freedom House rating, press is evaluated as not free and the overall score for the country is "partly free" (Freedom House, online 2015). Despite of the fact that the democracy ratings are still better that 1999-2002 period, the situation of the freedom of media is a cause of concern for Turkish democracy.

\section{Conclusion: A Comparison of the Accession Process of Serbia and Turkey and the Impact of}

\section{Conditionality}

Through a comparison of the EU prospect of Serbia and Turkey, this paper tried to argue that conditionality may work differently and there can be an obvious pace difference in the accession processes. Even reviewing some key dates for the development of relations of the two countries with the EU demonstrates the considerable pace difference in the membership processes. The first relations between Turkey and the European Union have started in 1959. Turkey applied for associate membership and in 1963 the Association Agreement was signed between the two parties. The EU and Serbia relations, which was established in 1989 after the dissolution of Yugoslavia, have developed after the end of Slobodan Milosevic rule. The association agreement between Serbia and the EU was signed in 2008. Turkey applied for full membership in 1987 and was accepted as a candidate country in 1999. It took six more years for the accession negotiations to start, which took place in 2005. Serbia, on the other hand, applied for full membership in 2011 and was accepted as candidate in 2012. The negotiation process has started by the beginning of 2014.

The temporal dimension of the difference of the accession processes of Serbia and Turkey evokes a question: Do the conditions work the same for all candidate countries? The conditionality of membership 


\section{BUJSS}

9/1 (2016), 118-133

differed for two countries both in terms of quality and quantity. The first and the most important condition for the membership of Serbia was the arrest and extradition of the war criminals to the ICTY. With the fulfillment of this criterion, Serbia gained official candidate status. However, for the same position Turkey was expected to fulfill various criteria, starting from the economic criterion to political, including human rights, minority rights and democracy, all of which Turkey needs significant advancement. On the other hand, gaining membership status can help to stimulate the satisfaction of political criteria, as it was the case for Spain and Portugal. Moreover, the criteria lists for Turkey have been multiplying in time, with the addition of good neighborhood relations, particularly with Greece and Cyprus. Thus, the conditions for Turkey did not stay stable and attainable, but they are developing in time, as new requirements emerged with the inclusion of the Republic of Cyprus into the EU.

Regarding relations with neighbors, both countries experience difficulty particularly in their relations with Kosovo and Cyprus. Serbia is given credit for non-aggression towards Kosovo, despite of not formally recognizing her. Turkey on the other hand, faces sanctions for un-recognizing the Republic of Cyprus, which was given membership without solving the ethnic conflict with Turkish Cypriots.

As the last comparison area, the free movement clause is implemented completely different for the two countries. The 1963 Association Agreement gives Turkey free movement of workers and establishment rights with Articles 12 and $13^{4}$. Again in 1970 Additional Protocol, these rights were mentioned and were expected to be realized between 12th and 22nd years of the Association Agreement. Article 41 of the same protocol declares that parties shall refrain from introducing restrictions on these rights; however, in contemporary implementation Turkish citizens are subject to strict visa regulations. In a European Court of Justice Case in 2009, the Court approved a Turkish citizen's claim of violation of free movement rights (Official Journal of the European Union; 2009). However, in practice these rights are still violated and all European member states require visa for Turkish citizens. For Serbia, the free movement right was given even before the membership application, with a visa facilitation agreement in 2008 . That shows a significant difference of attitude from the EU towards the citizens of the two countries.

After reviewing these three areas to see whether the pace of membership was different for the two countries, the reasons for the difference should be overviewed. Size and population can be perceived as important factors in this difference. The impact of these factors can be seen from the candidacy document of Serbia, in which it was stated that “...Serbia's accession would have a limited overall impact on European Union policies and would not affect the Union's capacity to maintain and deepen its own development" (Communication, 2011; 1). As it can also be seen from this statement, size and population are factors that

\footnotetext{
${ }^{4}$ Articles declare that the contracting parties agree to be guided by the relevant articles of the Treaty establishing the Community for the purpose of progressively securing freedom of movement for workers and abolishing restrictions on freedom to provide services. 1963 Ankara Agreement, online: http://ec.europa.eu/enlargement/pdf/turkey/association_agreement_1964_en.pdf (09.03.2014)

1970 Additional Protocol, online: http://eur-lex.europa.eu/LexUriServ/LexUriServ.do?uri=CELEX:21970A1123(01):EN:HTML, (09.03.2014)
} 


\section{BUJSS}

9/1 (2016), 118-133

the EU gives importance to and Serbia's size and population are absorbable for the EU. On the other hand, with the large population Turkey will change the balance in decision making bodies, and with her growing economy and geographical location, will have a bigger impact on the policies of the EU. When comparing the sizes of both countries, it is expected that Turkey's accession process would be longer. However, the pace difference, as tried to be shown throughout this article, is considerably negative for Turkey and this, in turn, can negatively affect the belief and endeavor of Turkey to realize the reforms that are necessary to reach membership.

Turkey's size and democracy are factors that can cause the prolonged candidacy. However, as the least expressed but maybe the most influential factor, culture and religion should also be taken into consideration. The question remains important and unanswered; is the reason behind the different pace of candidacy and membership for the two countries technical problems or European identity? At this point, it is the EU that needs to clarify the logic behind the enlargement; enlargement as "Europeanization" or enlargement as “EU-izaton” (Sjursen, 2002; 504, Müftüler-Bac, McLaren, 2003; 23, Keyman, Öniş, 2007; 92-94). 


\section{BUJSS}

9/1 (2016), 118-133

\section{Bibliography}

Additional Protocol (1970). Online: http://eur-lex.europa.eu/LexUriServ/LexUriServ.do?uri=CELEX:21970A1123(01):EN:HTML, (09.03.2014).

Akgül A., S. (2010), "Cycles of Europeanization in Turkey: The Domestic Impact of EU Political Conditionality”, UNISCI Discussion Papers, No 23, pp.129-148.

Ankara Agreement (1963). Online: http://ec.europa.eu/enlargement/pdf/turkey/association_agreement_1964_en.pdf, (09.03.2014).

Balkır, C. (1998), “The Customs Union and Beyond”, in: Libby Ritenberg (Ed.). The Political Economy of Turkey in the Post-Soviet Era: Going West and Looking East? Westport: Conn: Greenwood Press, pp. 52-77. Commission of the European Communities (2004), Communication from the Commission to the Council and the European Parliament, Recommendation of the European Commission on Turkey's progress towards accession, Brussels, COM (2004) 656 final, 6.10.2004. Online: http://eur-lex.europa.eu/legal-content/EN/TXT/PDF/?uri=CELEX:52004DC0656\&from=EN, (19.03.2014).

Commission of the European Communities (2005), Communication from the Commission: 2005 enlargement strategy paper, COM (2005) 561 final, Brussels, 09.11.2005. Online: http://eur-lex.europa.eu/legal-content/EN/TXT/PDF/?uri=CELEX:52005DC0561\&from=EN, (19.03.2014).

Commission of the European Communities (2007a), Serbia 2007 Progress Report, 6.11.2007, SEC (2007)

1435. Online: http://ec.europa.eu/enlargement/pdf/key_documents/2007/nov/serbia_progress_reports_en.pdf (19.03.2014).

Commission of the European Communities (2007b), Communication from the Commission to the European Parliament and the Council: Enlargement Strategy and Main Challenges 2007-2008, SEC (2007) 663 final. Online: http://ec.europa.eu/enlargement/pdf/key_documents/2007/nov/strategy_paper_en.pdf, (19.03.2014). Commission of the European Communities (2008), Serbia 2008 Progress Report, 5.11.2008, SEC (2008) 2698 final. Online: http://ec.europa.eu/enlargement/pdf/press_corner/key-documents/reports_nov_2008/serbia_progress_report_en.pdf, (19.03.2014).

Commission of the European Communities (2009), Serbia 2009 Progress Report, 14.10.2009, SEC (2009)

1339. Online: http://ec.europa.eu/enlargement/pdf/key_documents/2009/sr_rapport_2009_en.pdf, (19.03.2014).

Commission of the European Communities, Commission Staff Working Paper (2002), Federal Republic of Yugoslavia, Stabilization and Association Report, Brussels, SEC 343. 


\section{BUJSS}

9/1 (2016), 118-133

Online: http://ec.europa.eu/enlargement/archives/pdf/serbia_and_montenegro/com02_343_en.pdf, (19.03.2014).

Communication from the Commission to the Council and the European Parliament (2009), "Enlargement Strategy and Main Challenges 2009-2010", Conclusions on Serbia, COM (2009) 533 final. Online: http://ec.europa.eu/enlargement/pdf/key_documents/2009/conclusions_on_serbia_en.pdf, (19.03.2014). Communication from the Commission to the Council and the European Parliament (2011), "Enlargement Strategy and Main Challenges 2011-2012", Conclusions on Serbia, COM (2011) 666, 2011. Online: http://ec.europa.eu/enlargement/pdf/key_documents/2011/package/sr_conclusions_2011_en.pdf, (19.03.2014).

Energy Community (2015), About Us. Online: https://www.energy-community.org/portal/page/portal/ENC_HOME/ENERGY_COMMUNITY, (11.01.2016).

Eralp, A. (1998), "Turkey and the European Union in the Aftermath of the Cold War", in: The Political Economy of Turkey in the Post -Soviet Era: Going West and Looking East, L. Rittenberg (Ed.), Westport Connecticut: Greenwood Publishing Group Inc.

Eralp, A. (2004), “Turkey and the European Union”, in: The Future of Turkish Foreign Policy, Lenore G. Martin and Dimitris Keridis (Eds.), Cambridge: The MIT Press.

European Commission (2015), Enlargement: EU - Turkey relations. Online: http://ec.europa.eu/enlargement/candidate-countries/turkey/eu_turkey_relations_en.htm, (07.12.2015).

European Commission, (2005), Serbia and Montenegro: 2005 Progress Report, SEC (2005) 1428, Brussels. Online: http://www.europarl.europa.eu/RegData/docs_autres_institutions/commission_europeenne/sec/2005/1428/COM_SEC(2005)1428_EN.pdf, (07.12.2015). European Commission, (2013), Turkey 2013 Progress Report, Brussels, SWD (2013) 417 final. Online: http://www.abgs.gov.tr/files/strateji/tr_rapport_2013_en.pdf, (18.03.2014).

European Commission, (2014), Turkey 2014 Progress Report, Brussels. Online: http://ec.europa.eu/enlargement/pdf/key_documents/2014/20141008-turkey-progress-report_en.pdf, (18.03.2014).

European Council (2014), Decision 2006/56/EC, Official Journal, L 035. Online: http://eur-lex.europa.eu/LexUriServ/LexUriServ.do?uri=CELEX:32006D0056:EN:HTML, (10.03.2014).

European Council in Copenhagen (1993), Conclusions of the Presidency, SN 180/1/93 REV 1. Online: http://ec.europa.eu/bulgaria/documents/abc/72921_en.pdf, (18.03.2014). 


\section{BUJSS}

9/1 (2016), 118-133

European Parliament (2014), Conclusions of the Presidency, Santa Maria da Feira European Council.

Online: http://www.europarl.europa.eu/summits/feil_en.htm\#V, (11.03.2014).

European Union (2006), Consolidated versions of the Treaty on European Union and of the treaty

establishing the European Community, Official Journal of the European Union, C 321/E. Online: https://www.ecb.europa.eu/ecb/legal/pdf/ce32120061229en00010331.pdf, (11.01.2015).

Freedom House (2015), Turkey 2015. Online: https://freedomhouse.org/report/freedom-world/2015/turkey, (14.12.2015).

General Affairs and External Relations, (2013), External Relations, 2518th Council meeting, 10369/03

(Presse 166), Luxemburg. Online: http://www.consilium.europa.eu/ueDocs/cms_Data/docs/press-

Data/en/gena/76201.pdf, (11.03.2014).

Hale, W. (2003), "Human Rights, the European Union and the Turkish Accession Process", Turkish Studies, Vol.4, N.1, pp.107-126.

Keyman, E.F., Öniş, ZZ (2007), Turkish Politics in a Changing World, İstanbul: İstanbul Bilgi Üniversitesi Yayınlar1.

Lazic, M., Vladimir V. (2009), “The Nation State and the EU in the Perceptions of Political and Economic Elites: The Case of Serbia in Comparative Perspective”, Europe-Asia Studies, 61/6, .987-1001.

Müftüler-Bac, M. (1997), “Turkey and the European Union: an historical overview”, in: Turkey’s Relations with a Changing Europe, UK: Manchester University Press.

Müftüler-Bac, M., McLaren L. (2003), "Enlargement Preferences and Policy-making in the European Union: Impacts on Turkey", European Integration, 25,17-30.

Official Journal of the European Union (2009), Court Proceedings, Case C-228/06, C90/2. Online: http://eur-lex.europa.eu/LexUriServ/LexUriServ.do?uri=OJ:C:2009:090:0002:0002:EN:PDF, (09.03.2014).

Orlovic, S. (2008), "Parties and the party system of Serbia and European integrations”, Journal of Southern Europe and the Balkans, 10/2, 205-222.

Öniş, Z. (2000), “Luxemburg, Helsinki and Beyond: Towards an Interpretation of Recent Turkey-EU Relations", Government and Opposition, 35/4, 463-483.

Pavlovic', D., Antonic S (2007), Konsolidacija demokratskih ustanova u Srbiji posle 2000, Godine, Belgrade: Sluz`beni glasnik, in: Sabrina P. Ramet, “Crotia and Serbia since 1991: An Assessment of Their Similarities and Differences", Journal of Communist Studies and Transition Politics, 27/2, 263-290.

Presnall, A. (2009), "Which way the wind blows: democracy promotion and international actors in Serbia", Democratization, 16/4, .661-681. 


\section{BUJSS}

9/1 (2016), 118-133

Ramet, S. P. (2011), "Croatia and Serbia since 1991: An Assessment of Their Similarities and Differences", Journal of Communist Studies and Transition Politics, 27/2, 263-290.

Renner, S. Florian T. (2009), "Creeping EU Membership in South-east Europe: The Dynamics of EU Rule Transfer to the Western Balkans", Journal of European Integration, V.3/4, 449-465.

Schimmelfennig, F. (2008), "EU political accession conditionality after the 2004 enlargement: consistency and effectiveness", Journal of European Public Policy, 6/15, 918-937.

Sjursen, H., (2002), "Why Expand? The Question of Legitimacy and Justification in the EU's Enlargement Policy”, JCMS, 40/3, 491-513.

Smith, K. E., (2005), "Enlargement and European Order”, in: Christopher Hill and Michael Smith (Eds.). International Relations and the European Union. Oxford: Oxford University Press, 270-291.

The European Community (2011), Stabilization and Association Agreement between the European Communities and Their Member States of the One Part and the Republic of Serbia, of the Other Part, CE/SE7en 1, Online: http://ec.europa.eu/enlargement/pdf/serbia/key_document/saa_en.pdf, (18.03.2014). Tocci, N. (2012), "Regional origins, global aspirations: The European Union as a global conflict manager", in: Conflict Management in Divided Societies, Stefan Wolff, Christalla Yakinthou (Eds.), London: Routledge, 135-150.

Weller, M. (2012), “The failure of prevention: Kosovo”, in: Conflict Management in Divided Societies, Stefan Wolff, Christalla Yakinthou (Eds.), London: Routledge, .217-232.

Yakinthou, C. (2012) “A never-ending story: Cyprus”, in: Conflict Management in Divided Societies, Stefan Wolff, Christalla Yakinthou (Eds.), London: Routledge, 233-248. 